\title{
Arkadiusz Niedziółka
}

Uniwersytet Rolniczy w Krakowie

\section{Zarządzanie strategiczne i marketingowe w turystyce kulturowej na obszarach wiejskich powiatu nowotarskiego}

\begin{abstract}
Streszczenie. Praca przedstawia koncepcje zarządzania marketingowego oraz strategicznego w wiejskiej turystyce kulturowej stosowane w powiecie nowotarskim przez władze lokalne oraz stowarzyszenia agroturystyczne. W części teoretycznej artykułu opisano na podstawie literatury przedmiotu metody marketingowo-zarządcze realizowane w rozwoju tej turystyki. Zaprezentowano najważniejsze walory turystyczne regionu badań. Popularna tutaj jest turystyka kulturowa polegająca na poznawaniu przez turystów lokalnego folkloru, dziedzictwa kulturowo-historycznego, uczestniczenia w różnych imprezach kulturowych oraz zwiedzania zabytków architektury (np. zamków, dworów), muzeów i skansenów. W części empirycznej przedstawiono wyniki badań ankietowych przeprowadzonych we wszystkich gminach wiejskich i miejsko-wiejskich powiatu nowotarskiego. Ukazano ponadto wyniki badań przeprowadzonych z prezesami dwóch stowarzyszeń agroturystycznych. Wszystkie badania miały na celu przedstawienie koncepcji zarządzania strategicznego i marketingowego w rozwoju wiejskiej turystyki kulturowej.
\end{abstract}

Słowa kluczowe: wiejska turystyka kulturowa, agroturystyka, folklor, zarządzanie, dziedzictwo kulturowo-historyczne

\section{Wstęp}

Dotychczasowe aspekty dotyczące zarządzania w wiejskiej turystyce kulturowej najczęściej odnosiły się do różnych koncepcji zarządzania turystyką wiejską lub agroturystyką. W licznych opracowaniach poruszana była problematyka turystyki kulturowej, w tym jej zarządzanie. Stanowiło to jednak część składową różnych koncepcji zarządzania (strategicznego, marketingowego, promocją, jakością) szeroko rozumianej turystyki na terenach wiejskich.

W wielu publikacjach naukowych związanych z marketingiem w agroturystyce wskazywano na potrzebę uwzględnienia w produkcie agroturystycznym walorów kulturowych, folkloru i dziedzictwa kulturowo-historycznego regionu ${ }^{1}$. Także w artykułach

\footnotetext{
${ }^{1}$ M. Jalinik: Agroturystyka na obszarach przyrodniczo cennych, Wydawnictwo Politechniki Białostockiej, Białystok 2002, s. 47; B. Mikuta, K. Żelazna: Organizacja ruchu turystycznego na wsi, Wydawnictwo FORMAT-AB, Warszawa 2004, s. 132-133; M. Jalinik: Typologia gospodarstw agroturystycznych jako determinanta rozwoju usług, Wydawnictwo Politechniki Białostockiej, Białystok, s. 100-104;

$凶_{\text {a.niedziolka@ur.krakow.pl }}$ 
naukowych dotyczących turystyki wiejskiej, aspektów marketingowych, zarządzania marketingowego jako istotnych czynników jej rozwoju poruszano tematykę turystyki kulturowej na wsi².

Jedną z najważniejszych koncepcji zarządzania turystyką na obszarach wiejskich jest zarządzanie marketingowe. Zbliżona koncepcja to zarządzanie strategiczne - dotyczy planów strategicznych związanych z rozwojem usług turystycznych na wsi. W różnych pozycjach naukowych wskazywano na dużą rolę strategii rozwoju turystyki na obszarach wiejskich i na różne przedsięwzięcia z tym związane ${ }^{3}$. W wielu z nich odnoszono się także do zagadnień wiejskiej turystyki kulturowej.

Związana jest ona z ciekawym pod względem turystycznym regionem Małopolski jakim jest powiat nowotarski. Na jego obszarze znajdują się liczne zabytki architektury, m.in. drewniane kościółki w Dębnie Podhalańskim (Lista światowego dziedzictwa UNESCO), Harklowej, Łopusznej, Grywałdzie, Sromowcach Niżnych, murowane kościoły na Spiszu (np. Kacwin, Łapsze Wyżne, Dursztyn), znane sanktuaria (np. w Ludźmierzu), muzea (np. Tischnerówka w Łopusznej), skanseny (np. w Zubrzycy Górnej), zamki w Czorsztynie i w Niedzicy-Zamek. Kultywuje się w regionie ciekawe dziedzictwo kulturowo-historyczne oraz folklor, które głównie są propagowane przez Spiszaków, Orawian i górali pienińskich.

Celem opracowania jest przedstawienie dwóch koncepcji zarządzania wiejską turystyką kulturową w powiecie nowotarskim, mianowicie zarządzania marketingowego oraz strategicznego. Koncepcje te stosują przeważnie samorządy gminne i stowarzyszenia agroturystyczne. Na początku 2017 r. (w okresie zimowym) przeprowadzono we wszystkich jedenastu gminach wiejskich powiatu nowotarskiego i w dwóch miejsko-

J. Sikora: Agroturystyka. Przedsiębiorczość na obszarach wiejskich, Wydawnictwo C.H. Beck, Warszawa 2012, s. 214; M. Czerwińska-Jaśkiewicz: Marketing w agroturystyce. Ujęcie segmentacyjne, Wydawnictwo Difin, Warszawa 2013, s. 88-90; W. Kuźniar: Aktywność marketingowa gmin i jej oddziaływanie na rozwój turystyki wiejskiej, Wydawnictwo Uniwersytetu Rzeszowskiego, Rzeszów 2013, s. 105-106.

${ }^{2}$ A.P. Wiatrak: Rynek i produkt w turystyce wiejskiej, [w:] A.P. Wiatrak (red.), Marketing i produkty markowe w turystyce wiejskiej, Wydawnictwo SGGW, Warszawa 1998, s. 14-15; A. Bott-Alama: Uwarunkowania rozwoju turystyki wiejskiej w województwie zachodniopomorskim, Wydawnictwo Naukowe Uniwersytetu Szczecińskiego, Szczecin 2005, s. 58; A. Balińska, I. Sikorska-Wolak: Turystyka wiejska szansą rozwoju wschodnich terenów przygranicznych na przykładzie wybranych gmin, Wydawnictwo SGGW, Warszawa 2009, s. 29-30; M. Maćkowiak, P. Seelieb: Wioski tematyczne jako forma aktywizacji turystycznej obszarów wiejskich, [w:] I. Sikorska-Wolak (red.), Turystyczne funkcje obszarów wiejskich, Wydawnictwo SGGW, Warszawa 2009, s. 35; J. Kosmaczewska: Turystyka jako czynnik rozwoju obszarów wiejskich, Bogucki Wydawnictwo Naukowe, Poznań 2013, s. 40; J. Majewski: Innowacyjność wiejskich produktów turystycznych, [w:] W. Kamińska (red.), Innowacyjność w turystyce wiejskiej a nowe możliwości zatrudnienia na obszarach wiejskich, Polska Akademia Nauk. Komitet Przestrzennego Zagospodarowania Kraju, Warszawa 2015, s. 14-15.

${ }^{3}$ B. Lane, J. Majewski: Turystyka wiejska i rozwój lokalny, Fundacja Fundusz Współpracy, Poznań 2001, s. 14-28; A. Balińska, I. Sikorska-Wolak: Turystyka wiejska szansą rozwoju wschodnich terenów przygranicznych na przykładzie wybranych gmin, Wydawnictwo SGGW, s. 29-30; W. Krupińska: Strategia rozwoju turystyki a proces kreowania nowych miejsc pracy na obszarach wiejskich, [w:] M. Kłodziński, W. Dzun (red.), Aktywizacja wiejskich obszarów problemowych, Instytut Rozwoju Wsi i Rolnictwa w Warszawie, Warszawa 2003, s. 113. 
-wiejskich (Rabka-Zdrój i Szczawnica) badania ankietowe nt. aspektów zarządczych w lokalnej turystyce kulturowej. Narzędziem badawczym był kwestionariusz ankiety, dodatkowo analizie poddano dokumenty strategiczne gmin dotyczące strategii ich rozwoju. Skupiono sie na kwestiach związanych z turystyką wiejską i agroturystyką. Kolejne narzędzie badawcze to kwestionariusz wywiadu - dotyczył wywiadów przeprowadzonych z prezesami dwóch stowarzyszeń agroturystycznych: Góralskiego Stowarzyszenia Agroturystycznego oraz Stowarzyszenia Turystyki i Agroturystyki Ziem Górskich. Wszystkie badania dotyczyły zarządzania marketingowego oraz strategicznego w rozwoju wiejskiej turystyki kulturowej w powiecie nowotarskim.

\section{Wiejska turystyka kulturowa w świetle literatury}

Turystyka kulturowa jest formą turystyki krajoznawczej i dotyczy partycypowania w kulturze, integracji z nią i lepszego jej rozumienia ${ }^{4}$. Polega na zwiedzaniu w miejscach recepcji turystycznej różnych zabytków architektury, np. zamków, pałaców, dworów, zabytkowych chat wiejskich, kościołów czy klasztorów. Wiąże się z poznawaniem folkloru, obyczajów i dziedzictwa kulturowo-historycznego regionów odwiedzanych ${ }^{5}$.

Turystyka kulturowa jest rozpowszechniona zarówno w miastach, jak i na obszarach wiejskich. Do głównych motywów związanych z jej uprawianiem T. Jędrysiak zalicza ${ }^{6}$ :

- poznanie nowych miejsc, społeczności i kultur,

- zainteresowanie sztuką, architekturą i historią,

- uczestnictwo w wydarzeniach kulturalnych i artystycznych,

- pobudki sentymentalno-etniczne (powrót do korzeni),

- aspekty religijne i kulturowe.

T. Buczkowska uważa, że celem uprawiania wiejskiej turystyki kulturowej jest poznanie dziedzictwa kulturowego i kultury współczesnej wybranego regionu, wsi albo małego miasta ${ }^{7}$. Podobnie tę turystyki określa A. Mikos von Rohrscheidt, który twierdzi, że stanowią ją wszystkie przedsięwzięcia o charakterze turystycznym, dla których głównym celem jest miejsce lub obszar mało zurbanizowany, a najważniejszy motyw jej uprawiania to chęć zapoznania się z żywą kulturą lub reliktami dawnej kultury tego miejsca lub obszaru ${ }^{8}$.

Turystyka kulturowa pełni również funkcje ekonomiczne. Turyści, którzy zwiedzają zamki, dwory, izby regionalne, muzea, skanseny, płacąc za bilety wstępu do tych obiektów oraz kupując pamiątki turystyczne, przyczyniają się do ekonomicznych profitów społeczności lokalnej i poszczególnych gmin. Do licznych korzyści wynikających z rozwoju turystyki kulturowej dla regionu i wsi można zaliczyć m.in. ${ }^{9}$ :

\footnotetext{
${ }^{4}$ P. Różycki: Zakres wiedzy o turystyce, Wydawnictwo Proksenia, Kraków 2005, s. 75.

5 Ibidem.

${ }^{6}$ T. Jędrysiak: Turystyka kulturowa, Polskie Wydawnictwo Ekonomiczne, Warszawa 2008, s. 10.

${ }^{7}$ T. Buczkowska: Turystyka kulturowa, AWF, Poznań 2008, s. 56.

${ }^{8}$ A. Mikos von Rohrscheidt: Turystyka kulturowa. Fenomen. Potencjał. Perspektywy. Podręcznik akademicki, GWSHM Milenium, Gniezno 2008, s. 103.

${ }^{9}$ M. Drzewiecki: Pojęcie turystyki wiejskiej, [w:] Turyzm 1998, t. 8, z. 1, s. 24.
} 
- uzyskiwanie dochodów z działalności pozarolniczej,

- tworzenie nowych miejsc pracy w usługach towarzyszących (handel, transport, usługi bytowe i społeczne),

- nabywanie doświadczeń w zakresie przedsiębiorczości w efekcie prowadzenia działalności turystycznej,

- rozwój inicjatyw lokalnych,

- poprawę infrastruktury lokalnej,

- zachowanie dziedzictwa kulturowego wsi i ochronę krajobrazu,

- rozwój sztuki ludowej i rękodzieła,

- podnoszenie estetyki wsi, kontakt z innymi wzorcami kulturowymi, rozwój osobowy mieszkańców wsi.

Aby turystyka kulturowa przyczyniła się do powstania powyższych korzyści, musi być wspierana przez władze lokalne i inne podmioty. Wsparcie powinno dotyczyć efektywnych działań promocyjnych różnych przedsięwzięć związanych z utrzymaniem dziedzictwa kulturowo-historycznego, zabytków architektury oraz organizacją imprez kulturowych, a także obejmować pomoc finansową.

\section{Zarządzania strategiczne i marketingowe w wiejskiej turystyce kulturowej}

W rozwoju wiejskiej turystyki kulturowej trzeba zwrócić uwagę na działalność marketingową, głównie promocję oraz odpowiednie nią zarządzanie. Do najczęściej spotykanych metod zarządzania zalicza się: zarządzanie strategiczne, zarządzanie marketingowe, w tym zarządzanie promocją oraz zarządzanie informacją.

Zarządzanie strategiczne wiąże się z opracowaniem strategii rozwoju gmin. W strategiach większości gmin wiejskich i miejsko-wiejskich w Polsce dużo miejsca poświęca się rozwojowi lokalnej gospodarki turystycznej. Często w dokumentach są zapisane różne działania wspierające jej rozwój, w tym wsparcie poszczególnych jej form, np. agroturystyki czy turystyki aktywnej. Najczęściej dotyczą one wsparcia działalności promocyjnej turystyki przez samorządy gminne i inne organizacje ${ }^{10}$. Również można w nich znaleźć postulaty związane z pozyskiwaniem środków unijnych na rozwój usług turystyczno-rekreacyjnych, współpracy z różnymi podmiotami w zakresie rozwoju turystyki w gminie.

Zarządzanie marketingowe odnosi się do działań zgodnych z filozofią marketingu, którego stosowanie jest podstawą rozwoju turystyki w gminie. Dotyczy ono także wiejskiej turystyki kulturowej. Obiekty noclegowe na wsi powinny w swojej ofercie zamieszczać informacje o dobrach kultury, które ich goście mogą zwiedzać. Wskazane jest, aby podkreślone zostały korzyści wynikające ze zwiedzania zabytków architektury oraz poznawania folkloru regionu.

Zarządzanie promocją to istotny rodzaj zarządzania marketingowego w turystyce. Promocja, obok produktu, dystrybucji i ceny to podstawowy element marketingu.

\footnotetext{
${ }^{10}$ A. Niedziółka: Współpraca instytucjonalna w zakresie promocji agroturystyki w województwie matopolskim, [w:] A. Rapacz (red.), Gospodarka turystyczna w regionie. Wybrane problemy funkcjonowania gmin i przedsiębiorstw turystycznych, Wydawnictwo Uniwersytetu Ekonomicznego we Wrocławiu, Wrocław 2013, s. 201.
} 
Według T. Sztuckiego, promocja „jest marketingowym oddziaływaniem na klientów i potencjalnych nabywców polegającym na dostarczaniu informacji, argumentacji i obietnic oraz zachęty, skłaniających do kupowania oferowanych produktów, jak również wytwarzających przychylną opinię o przedsiębiorstwach przemysłowych, handlowych i usługowych"11. Promocja w turystyce ma na celu informowanie potencjalnych turystów o atrakcjach danego regionu turystycznego, o jego walorach przyrodniczych i kulturowych, o ofercie obiektów hotelarskich, o obiektach sportowo-rekreacyjnych. Do najczęściej stosowanych instrumentów w działalności promocyjnej w turystyce można zaliczyć reklamę, sprzedaż osobistą, targi, giełdy, promocję uzupełniającą, a także public relations ${ }^{12}$.

\section{Wyniki badań}

Każda poddana badaniom gmina ma własną strategię rozwoju. Jest ona istotnym narzędziem w zarządzaniu ekonomiczno-społecznym rozwojem gmin i równocześnie ważnym instrumentem w zarządzaniu strategicznym i marketingowym lokalną turystyką. Zapisano w niej różne działania wspierające usługi turystyczno-rekreacyjne, w tym wsparcie dla turystyki kulturowej, a także podkreślono znaczenie folkloru oraz dziedzictwa kulturowego w rozwoju gospodarki turystycznej. W większości analizowanych dokumentów zapisano promocję walorów kulturowych.

We wszystkich strategiach zwrócono uwagę na pozytywne kwestie dotyczące turystyki. Głównie wskazywano atrakcyjne walory przyrodnicze i kulturowe, odpowiednie zagospodarowanie turystyczne, zróżnicowaną bazę noclegową, możliwości uprawiania różnych form turystyki wiejskiej, szczególnie agroturystyki, ekoturystyki, turystyki kwalifikowanej.

Respondenci wskazywali na różne formy wsparcia udzielane turystyce kulturowej. W każdym przypadku wskazywano na jej promocję w Internecie na oficjalnych stronach gmin oraz na różne wydawnictwa. W ramach komunikacji z rynkiem większość ankietowanych wymieniała także współpracę z różnymi podmiotami, w tym ze stowarzyszeniami agroturystycznymi, zespołami artystycznymi, kołami gospodyń wiejskich, a w czterech przypadkach z ośrodkiem doradztwa rolniczego. Zarządzanie promocją jest jedną z najbardziej rozpowszechnionych koncepcji zarządzania w turystyce stosowanych przez samorządy gminne.

Rozwój wiejskiej turystyki kulturowej związany jest mocno z rozwojem agroturystyki. W powiecie nowotarskim funkcjonują liczne gospodarstwa agroturystyczne, najwięcej działa ich w gminie Czorsztyn (180), następnie Krościenko nad Dunajcem (93), Łapsze Niżne (72) i Czarny Dunajec (54). W gminach Czorsztyn i Krościenko nad Dunajcem zarejestrowane są łącznie 273 gospodarstwa agroturystyczne, co stanowi prawie połowę wszystkich tego typu obiektów w całym powiecie nowotarskim (49\%). W pięciu gminach, w których część gospodarstw agroturystycznych należy do stowarzyszeń

\footnotetext{
11 T. Sztucki: Promocja - sztuka pozyskiwania nabywców, Agencja Wydawnicza „Placet”, Warszawa 1999, s. 177.

12 W.W. Gaworecki: Turystyka, Polskie Wydawnictwo Ekonomiczne, Warszawa 2003, s. 218-219.
} 
agroturystycznych, lub wszystkie działające są ich członkami (w gminach Lipnica Wielka i Spytkowice), władze lokalne prężnie współpracują z tymi organizacjami. Współpraca dotyczy głównie działań promocyjnych, w tym promocji walorów przyrodniczych i kulturowych w gminach.

Badania ankietowe przeprowadzono również z prezesami dwóch stowarzyszeń agroturystycznych: „Stowarzyszenia Turystyki i Agroturystyki Ziem Górskich” oraz „Góralskiego Stowarzyszenia Agroturystycznego". Ich celem było określenie koncepcji zarządzania marketingowego i strategicznego w rozwoju agroturystyki i wiejskiej turystyki kulturowej.

Góralskie Stowarzyszenie Agroturystyczne utworzono w 2009 roku z pienińsko-podhalańskiego oddziału stowarzyszenia Galicyjskie Gospodarstwa Gościnne. Na początku działalności liczba członków stowarzyszenia wynosiła 70 osób. W grupie tej było 25 gospodarstw agroturystycznych, 44 kwatery prywatne wynajmujące pokoje gościnne oraz 1 pensjonat. Obecnie organizacja liczy 74 członków, którzy prowadzą działalność turystyczną i agroturystyczną na obszarze dwóch powiatów: nowotarskiego i tatrzańskiego. Do stowarzyszenia należy 26 rolników zajmujących się agroturystyką. Inne zrzeszone podmioty (poza gospodarstwami agroturystycznymi) to wyciąg narciarski, klub sportowy, pensjonat oraz 45 kwater prywatnych. Organizacja jest również członkiem ogólnokrajowej Polskiej Federacji Turystyki Wiejskiej „Gospodarstwa Gościnne".

Góralskie Stowarzyszenie Agroturystyczne posiada 6 kół terenowych, w tym 4 z terenu powiatu nowotarskiego. Najliczniejsze jest koło w Czorsztynie, które zrzesza 18 członków, następnie z Krościenka nad Dunajcem (12 członków), koło terenowe w Jabłonce (9 członków) oraz koło terenowe Spisz (4 członków) ${ }^{13}$.

Stowarzyszenie współpracuje z samorządami terytorialnymi różnego szczebla. Są one jego partnerami w wielu projektach realizowanych na terenie działalności Góralskiego Stowarzyszenia Agroturystycznego. Zarządzanie projektami to pierwsza koncepcja zarządzania jaką stosuje stowarzyszenie. Zrealizowało ono 2 projekty. Pierwszy, zrealizowany w latach 2010-2011, był zatytułowany „Góralskie okno na świat przez internet - promocja regionu poprzez utworzenie strony internetowej Stowarzyszenia". Był to projekt złożony do Lokalnej Grupy Działania Gorce-Pieniny. Drugi, który został zrealizowany w latach 2011-2012, zatytułowany był: „Opracowanie i wydanie katalogu agroturystycznego promującego walory turystyczne regionu objętego działaniem LGD Spisz i Okolice oraz najbliższych okolic". Został on złożony do Stowarzyszenia Rozwoju Spisza i Okolicy. Finalizacją projektu było wydanie 5 tys. egzemplarzy katalogu z ofertę agroturystyczną członków Góralskiego Stowarzyszenia Agroturystycznego. W katalogu nie zabrakło również informacji o walorach kulturowych regionów nowotarskiego i tatrzańskiego.

$\mathrm{Na}$ oficjalnej stronie internetowej stowarzyszenia, oprócz typowej oferty agroturystycznej, zawarto wiele informacji dotyczących najważniejszych walorów turystycznych,

\footnotetext{
${ }^{13}$ http://www.goralskie.net/kolo.php (dostęp: 22.11.2017).
} 
przyrodniczych i kulturowych regionów, gdzie działają członkowie stowarzyszenia. Opisano zabytki architektury i folklor z pięciu krain geograficzno-historycznych: Gorców, Orawy, Pienin, Podhala i Spisza.

Zrzeszone w Góralskim Stowarzyszeniu Agroturystycznym gospodarstwa agroturystyczne promują również swoje usługi podstawowe i towarzyszące na oficjalnych portalach internetowych gmin, na terenie których prowadzą swoją działalność.

W rozwoju turystyki wiejskiej, agroturystyki, turystyki kulturowej ważne miejsce zajmuje także koncepcja zarządzania strategicznego. Stowarzyszenie planuje w przyszłości skorzystać ze środków UE z Programu Rozwoju Obszarów Wiejskich na lata 2014-2020 na rozwój agroturystyki. Ankietowany wskazał ponadto, że należy skuteczniej promować świadczone usługi turystyczne, wykorzystując do tego celu różne instrumenty promocyjne.

Badania ankietowe przeprowadzono również z prezesem Stowarzyszenia Agroturystyki i Turystyki Ziem Górskich. Organizacja ta została założona w 1998 r. przez 20 osób, w tym przez 10 rolników, którzy prowadzili wówczas działalność agroturystyczną oraz przez 10 innych osób nieświadczących usług agroturystycznych. W 2015 r. Stowarzyszenie Turystyki i Agroturystyki Ziem Górskich liczyło już 89 członków, w tym 80 gospodarstw agroturystycznych i 9 pensjonatów.

W chwili obecnej w stowarzyszeniu zrzeszonych jest 29 rolników zajmujących się agroturystyką z powiatu nowotarskiego ( $36 \%$ wszystkich gospodarstw agroturystycznych należących do stowarzyszenia). W gminie Czorsztyn znajduje się 10 tego typu obiektów, w gminie Szaflary - 8, w gminie Krościenko nad Dunajcem - 3, w gminach Ochotnica Dolna, Rabka oraz Szczawnica po 2, a w gminach Nowy Targ i Raba Wyżna po 1. Ponadto w miejscowościach: Czorsztyn, Szaflary i Szczawnica stowarzyszenie prowadzi punkty informacji agroturystycznej.

Stowarzyszenie współpracuje głównie z Polską Federacją Turystyki Wiejskiej Gospodarstwa Gościnne, której jest członkiem oraz z Małopolską Organizacją Turystyczną. Kooperacja dotyczy przeważnie wspólnych działań promocyjnych. Zarządzanie promocją to istotny element działalności marketingowej stowarzyszenia. Oprócz współpracy z wymienionymi organizacjami promuje też usługi swoich członków na własnym portalu internetowym, podczas wyjazdów na targi i giełdy agroturystyczne oraz turystyczne. Prowadzi ponadto działalność wydawniczą oraz różne formy public relations, $\mathrm{np}$. w postaci udziałów w sympozjach i konferencjach, giełdach turystycznych. We wszystkich narzędziach promocyjnych, oprócz ofert wypoczynkowych w gospodarstwach agroturystycznych, są zawarte informacje o walorach kulturowych i folklorze regionu nowotarskiego.

Koncepcja zarządzania strategicznego w działalności stowarzyszenia odnosi się do jego planów przyszłościowych dotyczących szczególnie udziału w targach turystycznych i agroturystycznych, budowy nowej strony internetowej, wydania nowego informatora agroturystycznego z ofertą członków stowarzyszenia. Rozmówca wskazał ponadto na plany związane z tworzeniem gospodarstw ekologicznych i tematycznych. Dodał, że $w$ instrumentach promocyjnych zawsze będą zawarte informacje związane $z$ walorami kulturowymi oraz folklorem i dziedzictwem kulturowo-historycznym regionu. 


\section{Podsumowanie}

Wiejska turystyka kulturowa jest jedną z wielu form turystyki możliwych do uprawiania w powiecie nowotarskim (m.in. dzięki wykorzystaniu dziedzictwa kulturowo-historycznego i folkloru). Jej rozwój zależy głównie od licznie występujących w regionie zabytków architektury (np. kościołów murowanych i drewnianych, pałaców, dworów), ciekawych ekspozycji muzealnych i skansenów.

Jednym z ważniejszych czynników determinujących rozwój wiejskiej turystyki kulturowej jest wsparcie otoczenia instytucjonalnego. Różne podmioty zaangażowane w rozwój turystyki wiejskiej i agroturystyki włączają się w promocję lokalnych i regionalnych walorów kulturowych, folkloru oraz dziedzictwa kulturowo-historycznego regionu.

Działalność związana z zarządzaniem strategicznym i zarządzaniem marketingowym w turystyce kulturowej na obszarach wiejskich powiatu nowotarskiego widoczna jest na przykładzie aktywności samorządów gminnych. Na podstawie przeprowadzonych badań, związanych ze wspomnianymi koncepcjami zarządzania w wiejskiej turystyce kulturowej można stwierdzić, że:

- w strategiach rozwoju gmin, w odniesieniu do turystyki, propagowane jest także dziedzictwo kulturowe,

- w zarządzaniu marketingowym w turystyce kulturowej głównie chodzi o zarządzanie promocją polegające na stosowaniu różnych instrumentów komunikacji z rynkiem,

- we współpracy ze stowarzyszeniami agroturystycznymi, które propagują walory kulturowe poszczególnych gmin, władze lokalny prężnie promują dobra kulturowe, zabytki architektury i lokalny folklor,

- zarządzanie marketingowe dotyczy także współpracy samorządów z gospodarstwami agroturystycznymi poprzez umieszczanie ich ofert na oficjalnych portalach internetowych gmin.

Wyniki badań przeprowadzonych z prezesami stowarzyszeń agroturystycznych pozwoliły na sformułowanie następujących wniosków:

- koncepcja zarządzania marketingowego w rozwoju agroturystyki i turystyki kulturowej stosowana przez obydwa stowarzyszenia odnosi się głównie do zarządzania promocją,

- organizacje wykorzystują różne instrumenty do promocji wiejskiej turystyki kulturowej, m.in. reklamę internetową, wydawnictwa oraz wyjazdy na giełdy turystyczne,

- stowarzyszenia zarządzają promocją w turystyce kulturowej w celu zachęcenia turystów do korzystania z noclegów u swoich członków (przeważnie gospodarstw agroturystycznych) oraz do zwiedzania lokalnych i regionalnych zabytków architektury, odwiedzania muzeów i skansenów, do poznawania folkloru oraz dziedzictwa kulturowo-historycznego obszarów recepcji turystycznej,

- w rozwoju turystyki kulturowej ważna jest współpraca między badanymi podmiotami a innymi organizacjami związanymi z turystyką na terenach wiejskich,

- zarządzanie strategiczne to druga istotna koncepcja zarządzania w rozwoju wiejskiej turystyki kulturowej,

- stowarzyszenia wprowadzają koncepcję zarządzania strategicznego w wiejskiej turystyce kulturowej, dążąc w przyszłości do jej efektywniejszej promocji, 
- organizacje te kładą nacisk na dalszą współpracę z innymi podmiotami w rozwoju turystyki kulturowej.

\section{Literatura}

Balińska A., Sikorska-Wolak I.: Turystyka wiejska szansą rozwoju wschodnich terenów przygranicznych na przykładzie wybranych gmin, Wydawnictwo SGGW, Warszawa 2009.

Bott-Alama A.: Uwarunkowania rozwoju turystyki wiejskiej w województwie zachodniopomorskim, Wydawnictwo Naukowe Uniwersytetu Szczecińskiego, Szczecin 2005.

Buczkowska K.: Turystyka kulturowa, AWF, Poznań 2008.

Czerwińska-Jaśkiewicz M.: Marketing w agroturystyce. Ujęcie segmentacyjne, Wydawnictwo Difin, Warszawa 2013.

Drzewiecki M.: Pojęcie turystyki wiejskiej, [w:] Turyzm 1998, t. 8, z. 1.

Gaworecki W.W.: Turystyka, Polskie Wydawnictwo Ekonomiczne, Warszawa 2003.

http://www.goralskie.net/kolo.php (dostęp: 22.11.2017).

Jalinik M.: Agroturystyka na obszarach przyrodniczo cennych, Wydawnictwo Politechniki Białostockiej, Białystok 2002.

Jalinik M.: Typologia gospodarstw agroturystycznych jako determinanta rozwoju usług, Wydawnictwo Politechniki Białostockiej, Białystok 2005.

Jędrysiak T.: Turystyka kulturowa, Polskie Wydawnictwo Ekonomiczne, Warszawa 2008.

Kosmaczewska J.: Turystyka jako czynnik rozwoju obszarów wiejskich, Bogucki Wydawnictwo Naukowe, Poznań 2013.

Krupińska W.: Strategia rozwoju turystyki a proces kreowania nowych miejsc pracy na obszarach wiejskich, [w:] M. Kłodziński, W. Dzun (red.), Aktywizacja wiejskich obszarów problemowych, Instytut Rozwoju Wsi i Rolnictwa w Warszawie, Warszawa 2003.

Kuźniar W.: Aktywność marketingowa gmin i jej oddziaływanie na rozwój turystyki wiejskiej, Wydawnictwo Uniwersytetu Rzeszowskiego, Rzeszów 2013.

Lane B., Majewski J.: Turystyka wiejska i rozwój lokalny, Fundacja Fundusz Współpracy, Poznań 2001.

Maćkowiak M., Seelieb P.: Wioski tematyczne jako forma aktywizacji turystycznej obszarów wiejskich, [w:] I. Sikorska-Wolak (red.), Turystyczne funkcje obszarów wiejskich, Wydawnictwo SGGW, Warszawa 2009.

Majewski J.: Innowacyjność wiejskich produktów turystycznych, [w:] W. Kamińska (red.), Innowacyjność w turystyce wiejskiej a nowe możliwości zatrudnienia na obszarach wiejskich, Polska Akademia Nauk. Komitet Przestrzennego Zagospodarowania Kraju, Warszawa 2015.

Mikos von Rohrscheidt A.: Turystyka kulturowa. Fenomen. Potencjał. Perspektywy. Podręcznik akademicki, GWSHM Milenium, Gniezno 2008.

Mikuta B., Żelazna K.: Organizacja ruchu turystycznego na wsi, Wydawnictwo Format-AB, Warszawa 2004.

Niedziółka A.: Współpraca instytucjonalna w zakresie promocji agroturystyki w województwie małopolskim, [w:] A. Rapacz (red.), Gospodarka turystyczna w regionie. Wybrane problemy funkcjonowania gmin i przedsiębiorstw turystycznych, Wydawnictwo Uniwersytetu Ekonomicznego we Wrocławiu, Wrocław 2013.

Różycki P.: Zakres wiedzy o turystyce, Wydawnictwo Proksenia, Kraków 2005.

Sikora J.: Agroturystyka. Przedsiębiorczość na obszarach wiejskich, Wydawnictwo C.H. Beck, Warszawa 2012.

Sztucki T.: Promocja - sztuka pozyskiwania nabywców, Agencja Wydawnicza „Placet”, Warszawa 1999.

Wiatrak A.P.: Rynek i produkt w turystyce wiejskiej, [w:] A.P. Wiatrak (red.), Marketing i produkty markowe w turystyce wiejskiej, Wydawnictwo SGGW w Warszawie, Warszawa 1998. 


\section{The strategic and marketing management of cultural tourism in rural areas of the Nowy Targ County}

Summary. The work presents conceptions of the marketing management and strategic management of rural cultural tourism used by local authorities and agritourism associations in Nowy Targ County. In the theoretical part of the article, the marketing and management methods, which are realized in this form of tourism were described on the ground of the source literature. The most important tourist values of the study region were presented. Cultural tourism, which involves learning by tourists local folklore, cultural and historical heritage, participation in various cultural events and visiting architectural monuments, castles, mansions, museums and open-air museums, is popular here. In the empirical part of the article, the results of surveys conducted in all rural and urban and rural communes in Nowy Targ County were presented. Moreover the results of surveys conducted with the chairmen of two agritourism associations were presented, too. All surveys aimed at specifying the conception of strategic management and marketing management in the development of rural cultural tourism.

Key words: rural cultural tourism, agritourism, folklore, management, cultural and historical heritage 